\title{
SCREENING OF CHEMICAL COMPONENTS IN THE PROTEIN HYDROLYZATE EXTRACT FROM VISCERA OF TILAPIA (OREOCHROMIS NILOTICUS) WITH COLOR ASSAY
}

\author{
Riyadi Putut Har ${ }^{1,4 *}$, Suprayitno Eddy ${ }^{2}$, Aulanni'am Aulanni'am ${ }^{3}$, Sulistiyati Titik Dwi ${ }^{2}$ \\ ${ }^{1}$ Postgraduate Program, Faculty of Fisheries and Marine Science, University of Brawijaya, \\ Indonesia \\ ${ }^{2}$ Faculty of Fisheries and Marine Science, University of Brawijaya, Indonesia \\ ${ }^{3}$ Laboratory of Biochemistry, University of Brawijaya, Indonesia \\ ${ }^{4}$ Faculty of Fisheries and Marine Science, University of Diponegoro, Indonesia \\ ${ }^{\star}$ E-mail: putut.riyadi@live.undip.ac.id
}

\begin{abstract}
The production of Tilapia increased the impact on the increase of fish waste, such as viscera. One of the efforts to overcome and reduce fishery waste are by using them optimally. One of the efforts is hydrolysis technology, which can produce extracts that have bioactivity. This research aimed to find out and obtain an overview of the chemical components in the protein hydrolyzate extract from viscera of Tilapia (Oreochromis niloticus). The screening was performed for flavonoids, alkaloids (Meyer, Dragendrof, Bouchardat), tannins, terpenoids (steroids, triterpenoids), polyphenols, and saponins. The color intensity or the precipitate formation was used as analytical responses to these assays. The results of screening and identification showed the presence of chemical components of alkaloids, tannins, triterpenoids, polyphenols, saponins from the protein hydrolyzate extract of viscera of Tilapia (Oreochromis niloticus), on the other hand, flavonoids and steroids were not detected. These chemical components have the potential bioactivity as antioxidants, anti-nociceptive, antiinflammatory, anti-HIV, anti-fungal, cardioprotective, immunoregulative, anti-malarial, antiinflammatory, Cerebro-protective, anti-mutagenic, vaso-relaxing, anti-bacterial, antianxiolytic, analgesic, anti-nociceptive and anxiolytic. The extract has the potential to be developed in the field of health as pharmaceutical or nutraceutical products.
\end{abstract}

\section{KEY WORDS}

Alkaloids, tannins, triterpenoids, polyphenols, saponins, pharmaceutical, nutraceutical.

Tilapia is one of the Indonesian fisheries commodities that are in high demand by domestic and foreign consumers. The demand for Tilapia commodities increases every year; this can be seen from increased Tilapia production. Production of Tilapia (Oreochromis niloticus) in Indonesia for 5 (five) years has increased by $18 \%$. The volume of Tilapia production in 2011 was 567,078 tons and improved in 2015 by 1,084,281 tons (Ariansyach, 2017).

The Processing of Tilapia usually only takes part in the white meat; the yield is $\pm 50 \%$. The waste from the production of Tilapia consists of scales, heads, bones, skin, and innards. The contents of the stomach or commonly called innards include liver, heart, spleen, hepatopancreas, gonads, ren, bile, and intestines. Tilapia waste has not been utilized. Even bones, skin, and stomach contents tend to be thrown away or discarded. This is very unfortunate because fishing industry waste, for example, viscera, has high levels of unsaturated fat and protein (Bhaskar \& Mahendrakar, 2008). The viscera of Tilapia still contains $16 \%$ protein (Khalil, 2012). One of the efforts to overcome and reduce fishery waste are by using them optimally. The processing of fishery waste products, including viscera, has been investigated as a source of protein, including enzymes and fats (Villamil, Váquiro, \& Solanilla, 2017).

The protein in an intact form has low bioactivity, whereas proteins that have been hydrolyzed by the enzyme will increase bioactivity because the protein has been separated from the long bonds fragments (Daliri, Oh, \& Lee, 2017). Bioactive peptides have potential as 
antihypertensive (Riyadi. 2018), antioxidants (Chi, Hu, Wang, Li, \& Luo, 2015), opioid antagonists, antibacterial (Hajfathalian, Ghelichi, García-Moreno, Moltke Sørensen, \& Jacobsen, 2017), antithrombotic, and immunomodulators (FitzGerald, Murray, \& Walsh, 2004). Peptides produced from food proteins can lower blood pressure, maintain weight balance (Liu, Wang, Peng, \& Wang, 2013), inhibit proline-specific endopeptidase activity, enhance the immune system, inhibit blood platelet aggregation, inhibit HIV proteinase and the oxidation process, have antibacterial, binds to ions and assists mineral transport and improves food nutritional value (Chakrabarti, Jahandideh, \& Jianping, 2014); (Li \& Yu, 2015); (Hayes, 2018). A number of research that utilize fisheries industry waste which have the potential to become bioactive peptides include the heads and innards and fish heads of sardine (Sardinella aurita) by Bougatef et al. (2008), innards and skin of squid (Sephia officianalis) (Balti et al., 2010), smoothhound innards (Mustelus mustelus) in Tunisia (Abdelhadi et al., 2016), and utilization of heads, fins and tails from Tilapia (Oreochromis niloticus) (Roslan, Faezah, Abdullah, \& Mazlina, 2014). This is an opportunity to develop waste protein innards of Tilapia into pharmaceutical or nutraceutical products.

This research aimed to find out and obtain an overview of the chemical components in the protein hydrolyzate extract from viscera of Tilapia (Oreochromis niloticus) based on the color assay. This research is expected to provide useful information about the chemical components of the extract to be developed in the field of health as pharmaceutical or nutraceutical products.

\section{MATERIALS AND METHODS OF RESEARCH}

The material used in this research was viscera of Tilapia from the freezing industry of PT Aquafarm Nusantara, Semarang Industrial Estate. Viscera of Tilapia was cleaned, where the fat covering the viscera was removed, then the viscera was weighed, and the hydrolysis process was carried out. The protease enzyme used was the enzyme alcalase (Sigma Aldrich) with activity of $\geq 0.75$ of Anson units $/ \mathrm{mL}$. The tools used were test tubes, test tube clamp, stainless steel spatula, drop pipette, measuring cup, Bunsen, glass funnel, micropipette, beaker glass, incubator, $1000 \mathrm{ml}$ Erlenmeyer, vacuum filter, rotary evaporator.

Viscera and distilled water (1: 1) were mixed using a blender until it became homogeneous, then it was heated at $85{ }^{\circ} \mathrm{C}$ for 20 minutes to inactivate endogenous enzymes. The samples were centrifuged at $10^{\circ} \mathrm{C}$ for 20 minutes at $5,800 \mathrm{rpm}$ to separate fat and protein, the fat was removed, and the result was a residue rich in protein. The protein in solids was extracted three times with distilled water at $1: 1(\mathrm{w} / \mathrm{v})$ to collect protein extracts until the fat was reduced. Protein extracts were hydrolyzed to the desired level with $1 \mathrm{~N}$ sodium hydroxide using a digital pH meter (Cyberscan 1001, Eutech, Singapore). The solution was activated at a temperature $(80-85)^{\circ} \mathrm{C}$ for 20 minutes to stop the hydrolysis process. After that, the sample was left at $4{ }^{\circ} \mathrm{C}$ for 24 hours and was cold centrifuged for 20 minutes and was dried using a freeze dryer. The degree of hydrolysis was calculated by the SN-TCA method (Hoyle \& Merrit, 1994) referenced in (Amiza, Kong, \& Faazaz, 2012). A total of $20 \mathrm{mg}$ of protein hydrolyzate was added to TCA of $10 \%(\mathrm{~b} / \mathrm{v})$ as much as $20 \mathrm{~mL}$. The mixture was then allowed to stand for 30 minutes for precipitation to occur, and then centrifuged (speed of $7,800 \mathrm{~g}$, for 15 minutes). The supernatant obtained was a protein hydrolyzate extract from viscera of Tilapia (Oreochromis niloticus). Then, further color assay will be carried out.

Screening and identification analysis of chemical components from the protein hydrolyzate extract from viscera of Tilapia (Oreochromis niloticus) based on color assay refers to the Harbone (1984) method, which is indicated by the color change of the extract after the addition of specific reagents. The parameters for the screening include flavonoids, alkaloids, tannins, terpenoids, polyphenols, and saponins. The data obtained are presented in table form and was analyzed descriptively, after that, a conclusion was drawn from the analysis.

Identification of Flavonoids. $2 \mathrm{ml}$ of sample extract was added with $8 \mathrm{ml}$ of aquadest, which was heated for \pm 10 minutes. The resulting filtrate was filtered and put in a test tube. 
Then a few drops of concentrated $\mathrm{HCl}$ was added. Next, a little mg powder was added. Positive result was indicated when dark red/pink colored filtrate was produced.

Identification of Alkaloids. $2 \mathrm{ml}$ of sample extract was added with $8 \mathrm{ml}$ of aquadest, which was heated for \pm 10 minutes. The resulting filtrate was filtered and put in a test tube. Then 6 drops of Meyer reagent were added to the first test tube, 6 drops of Dragendorf reagent were added to the second test tube, 6 drops of Bouchardat reagent were added to the third test tube. Positive result was indicated when white sediment was produced in Meyer's reagents, orange sediment was deposited in Dragendorf reagents and brown sediment was deposited in Bouchardat reagents.

Identification of Tanins. $2 \mathrm{ml}$ of sample extract was added with $8 \mathrm{ml}$ of aquadest, which was heated for \pm 10 minutes. The resulting filtrate was filtered and put in a test tube. Three drops of $\mathrm{FeCl}_{3} 1 \%$ was added to the filtrate. Positive result was indicated when either blackish brown, blackish blue or blackish green colored filtrate was produced.

Identification of Terpenoids. $2 \mathrm{ml}$ of sample extract was added with $8 \mathrm{ml}$ of aquadest, which was heated for \pm 10 minutes. The resulting filtrate was filtered and put in a test tube. Three drops of Bouchardat was added to the filtrate. Positive results contain steroids when bluish green colored filtrate was formed, and the results contain terpenoids when a brownish orange colored filtrate was formed.

Identification of Polyphenols. A total of $105 \mu \mathrm{g}$ of methanol extract was put into $206 \mathrm{~L}$ of $96 \%$ ethanol in a test tube. The mixture was added with $515 \mu \mathrm{L}$ of distilled water and $520 \mu \mathrm{L}$ of Follin-Ciocalteau reagent $(50 \% \mathrm{v} / \mathrm{v})$, then the mixture was left for 5 minutes. Then it was added with $103 \mu \mathrm{L}$ sodium carbonate solution $(7,5 \% \mathrm{~b} / \mathrm{v})$, was homogenized and incubated at room temperature for 1 (one) hour under no-light conditions (dark). Positive result was indicated when either blackish green, blackish blue, or blackish brown colored filtrate was formed.

Identification of Saponins. $2 \mathrm{ml}$ of sample extract was added with $8 \mathrm{ml}$ of aquadest, which was heated for \pm 10 minutes. The resulting filtrate was filtered and put in a test tube. Two $\mathrm{ml}$ of hot water was added to the filtrate. The test tube containing the filtrate then was shaken firmly. Positive result was indicated when the stable foam was not lost.

\section{RESULTS AND DISCUSSION}

Table 1 - Color Assays of the Protein Hydrolyzate Extract from Viscera of Tilapia for flavonoids and alkaloids

\begin{tabular}{|c|c|c|c|c|}
\hline \multirow{3}{*}{ Sample } & \multicolumn{4}{|c|}{ Chemical Components } \\
\hline & \multirow{2}{*}{ Flavonoids } & \multicolumn{3}{|c|}{ Alkaloids } \\
\hline & & Meyer & Dragendrof & Bouchardat \\
\hline $\begin{array}{c}\text { The protein hydrolyzate extract from viscera of } \\
\text { Tilapia (Oreochromis niloticus) }\end{array}$ & & & & \\
\hline
\end{tabular}

Table 2 - Color Assays of the Protein Hydrolyzate Extract from Viscera of Tilapia for tannins, triterpenoids, polyphenols, saponins

\begin{tabular}{|c|c|c|c|c|}
\hline \multirow{2}{*}{ Sample } & \multicolumn{3}{|c|}{ Chemical Component } \\
\cline { 2 - 4 } & Tannins & Triterpenoids & Polyphenols & Saponins \\
\hline $\begin{array}{c}\text { The protein hydrolyzate extract from viscera of } \\
\text { Tilapia (Oreochromis niloticus) }\end{array}$ & & & \\
\end{tabular}


Table 3 - Screening and Identification of Chemical Components in the Protein Hydrolyzate Extract from Viscera of Tilapia (Oreochromis niloticus)

\begin{tabular}{|l|l|l|l|}
\hline No & \multicolumn{1}{|c|}{ Chemical Components } & \multicolumn{1}{c|}{ Parameter } & Results \\
\hline 1 & Flavonoid & Brick red, pink, dark red & Negative \\
\hline \multirow{2}{*}{2} & Alkaloids & - & - \\
\cline { 2 - 4 } & Meyer Method & White sediment & Positive \\
\hline & Dragendrof Method & Orange sediment & Positive \\
\hline & Bouchardat Method & Brown sediment & Positive \\
\hline 3 & Tannins & Blackish green, blackish blue, blackish brown & Positive \\
\hline 4 & Steroids & Bluish green & Negative \\
\hline 5 & Triterpenoids & Orange, Brownish orange & Positive \\
\hline 6 & Polyphenols & Blackish green, blackish blue, blackish brown & Positive \\
\hline 7 & Saponins & Stable foam & Positive \\
\hline
\end{tabular}

The qualitative results of chemical component screening using Harbone (1983) method found that protein hydrolyzate extract of viscera of Tilapia (Oreochromis niloticus) contained alkaloids (table 1 and 3). Pelletier (1983) defined alkaloids as cyclic compounds containing nitrogen in a negative oxidation state, which is a limited distribution between living organisms. Alkaloids almost always have physiological activity in animals, although some have limited effects (Seigler, 1998). Alkaloids have benefits as tranquilizers (Guides et al., 2005), antioxidants (Bribi et al., 2013), Anti-nociceptive (Bribi et al., 2015), Anti-inflammatory (Bribi et al., 2016). Even berberine alkaloids have activities as anti-HIV, anti-fungal, cardioprotective, immunoregulative, anti-malarial, anti-inflammatory, antioxidant, Cerebroprotective, anti-mutagenic, vaso-relaxing, anxiolytic, and analgesic activities (Akao et al., 2006).

Protein hydrolyzate extract of viscera of Tilapia (Oreochromis niloticus) contains tannins (table 2 and 3). Tannins are a heterogeneous group of water-soluble polyphenolic compounds of high molecular weight (500-3000 Daltons) - with as many as 20 hydroxyl groups - and are present in plants, foods and beverages (de Jesus et al., 2012). Tannins have antioxidant activities (Skrovankova, 2015), Anti-cancer (Gollucke et al., 2013), Antimicrobial (Marín et al., 2015), Cardioprotective, Anti-diabetic and anti-obesity (GonzalezAbuin et al., 2015).

Protein hydrolyzate extract of viscera of Tilapia (Oreochromis niloticus) contains triterpenoid compounds (table 2 and 3 ). About $60 \%$ of known natural products are terpenoids (Firm, 2010). Triterpenoids have activities as anti-inflammatory and anti-cancer potential (Salminen et al., 2008), antioxidants (Melanie, 2009), anti-colon cancer, Hepatoprotective, anti-bacterial, anti-anxiolytic, Analgesic and Anti-Nociceptive (Battineni, 2018).

Protein hydrolyzate extract of viscera of Tilapia (Oreochromis niloticus) contains polyphenol compounds (table 2 and 3). A growing body of research indicates that polyphenol consumption may play a vital role in health through the regulation of metabolism, weight, chronic disease, and cell proliferation. Over 8,000 polyphenols have thus far been identified, though their short- and long-term health effects have not been fully characterized (Lecour and Lamont, 2011). Animal, human and epidemiologic studies show that various polyphenols have antioxidant and anti-inflammatory properties that can have preventive and therapeutic effects for cardiovascular disease, neurodegenerative disorders, cancer, and obesity (PérezJiménez et al., 2010); (Singh et al., 2011).

Protein hydrolyzate extract of viscera of Tilapia (Oreochromis niloticus) contains saponins compounds (table 2 and 3). Saponins, according to Firdous et al. (2009); Apri (2014), is a non-polar active compound which has a strong surface and can create foam when the compound is shaken with water. Marliana et al. (2005); Octaviani (2009) stated that the emergence of foam indicates the presence of glycosides, which can form a foam in hydrolyzed water into glucose and other compounds. This can happen because saponin compounds also have a hydrophobic group, namely aglycone. The saponin structure consists of aglycones (triterpene or steroids) and glucose groups. The process of synthesizing glycosides is a detoxification process. In this detoxification process, it is possible for toxic compounds to be bound to crude extracts. Farnsworth (1996); Yoshikawa 
et al. (2005); Ruiz et al. (2005); Bakhuni (2005); Zhang et al. (2006) stated that saponins has many biological and pharmacological functions, including cardiotonic, hypoglycemic, hemolysis, hypocholesterolemic, immune modulator, hepatoprotection, antioxidant, anticardiogenic, anti-microbial, anti-inflammatory, low toxicity. Saponins may function as antibiotics and cholesterol-lowering agent, and it may also have biological effects, including as an anti-fungal, cytotoxic against tumor cells, hemolysis, immune activity, and anti-cancer.

\section{CONCLUSION}

The results of screening and identification showed the presence of chemical components of alkaloids, tannins, triterpenoids, polyphenols, saponins from the protein hydrolyzate extract of viscera of Tilapia (Oreochromis niloticus), on the other hand, flavonoids and steroids were not detected. The extract has the potential to be developed in the field of health as pharmaceutical or nutraceutical products.

\section{ACKNOWLEDGMENTS}

The authors express their gratitude to the Ministry of Finance and the Ministry of Research and Higher Education of the Republic of Indonesia for the opportunity given to obtain the 2016 LPDP BUDI-DN scholarship.

\section{REFERENCES}

1. Abdelhadi, O., Jridi, M., Jemil, I., Mora, L., Toldra, F., Aristoy, M.-C., Nasri, R. 2016. Combine biocatalytic conversion of smooth hound viscera: Protein hydrolysates elaboration and assessment of their antioxidant, anti-ACE and antibacterial activities. Food Research International, 86, 9-23.

2. Amiza, M. A., Kong, Y. L., \& Faazaz, A. L. 2012. Effects of degree of hydrolysis on physicochemical properties of cobia (rachycentron canadum) frame hydrolysate. International Food Research Journal, 19(1), 199-206.

3. Apri R. 2014. The active compound content and phytochemical test of Sinularia sp. and Lobophytum sp. from the waters of Pongok Island, South Bangka." Institut Pertanian Bogor, Indonesian [Tesis]: Institut Pertanian Bogor.

4. Ariansyach, I. 2017. Fisheries Country Profile: Indonesia. Retrieved from http://www.seafdec.org/fisheries-country-profile-indonesia/

5. Balti, R., Bougatef, A., Ali, N. E. H., Zekri, D., Barkia, A., \& Nasri, M. 2010. Influence of degree of hydrolysis on functional properties and angiotensin I-converting enzymeinhibitory activity of protein hydrolysates from cuttlefish (Sepia officinalis) by-products. Journal of the Science of Food and Agriculture, 90(12), 2006-2014. https://doi.org/10.1002/jsfa.4045

6. Battineni, Jainendra Kumar, Praveen Kumar Koneti, Vasudha Bakshi, Narender Boggula. 2018. Triterpenoids: A review. International Journal of Research in Pharmacy and Pharmaceutical Sciences, 3 (2): 91-96

7. Bhakuni, R. 2005. Bioactive Marine Natural Product. Anamaya Publishers, New Delhi, India.

8. Bhaskar, N., \& Mahendrakar, N. S. 2008. Protein hydrolysate from visceral waste proteins of Catla (Catla catla): Optimization of hydrolysis conditions for a commercial neutral protease. Bioresource Technology, 99(10), 4105-4111. https://doi.org/10.1016/j.biortech.2007.09.006

9. Bougatef, A., Nedjar-Arroume, N., Ravallec-Plé, R., Leroy, Y., Guillochon, D., Barkia, A., \& Nasri, M. (2008). Angiotensin I-converting enzyme (ACE) inhibitory activities of sardinelle (Sardinella aurita) by-products protein hydrolysates obtained by treatment with microbial and visceral fish serine proteases. Food Chemistry, 111(2), 350-356. https://doi.org/10.1016/j.foodchem.2008.03.074 
10. Bribi, Noureddine., Francisca Algieri, Alba Rodriguez-Nogales. 2015. Anti-nociceptive and anti-inflammatory effects of total alkaloid extract from fumaria capreolata. EvidenceBased Complementary and Alternative Medicine, 736895(7): 1-8.

11. Bribi, Noureddine., Francisca Algieri, Alba Rodriguez-Nogales. 2016. Intestinal antiinflammatory effects of total alkaloid extract from fumaria capreolata in the DNBS model of mice colitis and intestinal epithelial CMT 93 cells. Phytomedicine, (23): 901-913.

12. Bribi, Noureddine., Yacine Bouguezza, Fadila Maiza. 2013. Evaluation of erythrocytes toxicity and antioxidant activity of alkaloids of fumaria capreolata. Inter $\mathrm{J}$ of Pharma and Bio Scien, (4): 770-776

13. Chakrabarti, S., Jahandideh, F., \& Jianping, W. 2014. Food-Derived Bioactive Peptides on Inflammation and Oxidative Stress. BioMed Research International, 2014, 1-11. https://doi.org/10.1155/2014/608979

14. Chi, C., Hu, F., Wang, B., Li, Z., \& Luo, H. 2015. Influence of Amino Acid Compositions and Peptide Profiles on Antioxidant Capacities of Two Protein Hydrolysates from Skipjack Tuna (Katsuwonus pelamis) Dark Muscle, 2580-2601. https://doi.org/10.3390/md13052580

15. Daliri, E. B., Oh, D. H., \& Lee, B. H. 2017. Review: Bioactive Peptides. Foods, 6(32), 121. https://doi.org/10.3390/foods6050032

16. de Jesus NZ, de Souza Falcão H, Gomes IF, de Almeida Leite TJ, de Morais Lima GR, Barbosa-Filho Jmet. 2012. Tannins, peptic ulcers and related mechanisms. Int J Mol Sci, 13: 3203-3228.

17. Farnsworth, N. R., 1996. Biological and Phytochemical Screening of Plants, of Pharm. Sci., Vol 5, No. 3.

18. Firdous M, Koneri R, Sarvaraidu CH, Shubhapriya KH. 2009. NIDDM antidiabetic activity of saponins of Momordica cymbalaria in streptozotocin-nicotinamide NIDDM mice. Journal of Clinical and Diagnosis Research. 3: 1460-1465.

19. Firn, Richard. 2010. Nature's Chemicals. Oxford: Biology.

20. FitzGerald, R. J., Murray, B. A., \& Walsh, D. J. 2004. Hypotensive Peptides from Milk Proteins. The Journal of Nutrition, 134(4), 980S-988S. https://doi.org/10.1093/jn/134.4.980S

21. Gollucke AP, Aguiar O Jr, Barbisan LF, Ribeiro DA. 2013. Use of grape polyphenols against carcinogenesis: putative molecular mechanisms of action using in vitro and in vivo test systems. J Med Food, 16: 199-205.

22. Gonzalez-Abuin N, Pinent M, Casanova-Marti A, Arola L, Blay M, Ardevol A. 2015. Procyanidins and their healthy protective effects against type 2 diabetes. Curr Med Chem, 22: 39-50.

23. Guides DN, Leitao Da-Cunha EV, Fechine IM,. 2005. Protoberberine alkaloids, in: The alkaloids; Chemistry and Biology, 1 st edition, ISBN: 0-12-469562-0. Elsevier Academic Press, London

24. Hajfathalian, M., Ghelichi, S., García-Moreno, P. J., Moltke Sørensen, A.-D., \& Jacobsen, C. 2017. Peptides: Production, bioactivity, functionality, and applications. Critical Reviews in Food Science and Nutrition, 0(0), 1-33. https://doi.org/10.1080/10408398.2017.1352564

25. Harborne, J.B. 1984. Phytochemical methods, 2nd edition. Chapman And Hall Publications, Vol. 288.

26. Hayes, M. 2018. Food Proteins and Bioactive Peptides: New and Novel Sources, Characterisation Strategies and Applications. Foods (Vol. 7). https://doi.org/10.3390/foods7030038

27. Hoyle, N. T., \& Merrit, J. H. 1994. Quality of Fish Protein Hydrolysates from Herring (Clupea harengus). Journal of Food Science, 59(1), 76-79. https://doi.org/10.1111/j.1365-2621.1994.tb06901.x

28. Khalil, A. A. 2012. Protein Characterization of the Aqueous Soluble Phase of Acidfied and Autolyzed Bolti Fish (Tilapia nilotico) Viscera. Asian Journal of Biotechnology, 1-12. https://doi.org/10.3923/ajbkr.2012 
29. Lecour S, Lamont KT. 2011. Natural polyphenols and cardioprotection. Mini Rev Med Chem. (11):1191-1199. doi: 10.2174/13895575111091191

30. Li, Y., \& Yu, J. 2015. Research Progress in Structure-Activity Relationship of Bioactive Peptides. Journal of Medicinal Food, 18(2), 147-156. https://doi.org/10.1089/jmf.2014.0028

31. Liu, L., Wang, Y., Peng, C., \& Wang, J. 2013. Optimization of the preparation of fish protein anti-obesity hydrolysates using response surface methodology. International Journal of Molecular Sciences, 14(2), 3124-3139. https://doi.org/10.3390/ijms14023124

32. Marín L, Miguélez EM, Villar CJ, Lombó F. 2015. Bioavailability of dietary polyphenols and gut microbiota metabolism: antimicrobial properties. Biomed Res Int, 905215.

33. Marliana, S., V. Suryanti, Suyono. 2005. Skrining Fitokimia dan Analisis Kromatografi Lapis Tipis Komponen Kimia Buah Labu Siam (Sechium edule Jacq. Swartz.) dalam Ekstrak Etanol. Jurnal Biofarmasi Vol. 3(1): 26-31.

34. Melanie, Laszczyk,. 2009. Pentacyclic Triterpenes of the Lupane, Oleanane and Ursane Group as Tools in Cancer Therapy. Planta Medica, 75(15):1549-60.

35. Octaviani, Y. 2009. Isolasi dan Identifikasi Aglikon Saponin Kecambah Kacang Hijau (Phaseolus radiates L.). Jurusan Farmasi. Universitas Sanata Dharma. Yogyakarta.

36. Pelletier, S.W. 1996. Alkaloids: Chemical and Biological Perspectives, Volume 1. Institute for Natural Products Research, Chemistry Building, The University of Georgia, Athens, Pergamon Publish. pages 392. Georgia USA

37. Pérez-Jiménez J, Neveu V, Vos F, Scalber A. 2010. Identification of the 100 richest dietary sources of polyphenols: an application of the PhenolExplorer database. Eur J Clin Nutr, 64:S112-S120. doi: 10.1038/ejcn. 2010.221

38. Riyadi, P. H. 2018. Bioactive Peptide for Lowering Pressure Blood from Fisheris byProduct. J. Peng \& Biotek Hasil Pi, 7(1), 1-6. Retrieved from http://www.ejournals1.undip.ac.id/index.php/jpbhp

39. Roslan, J., Faezah, K., Abdullah, N., \& Mazlina, S. 2014. Characterization of Fish Protein Hydrolysate from Tilapia (Oreochromis niloticus ) by-Product. Agriculture and Agricultural Science Procedia, 2, 312-319. https://doi.org/10.1016/j.aaspro.2014.11.044

40. Ruiz N, Falcone B, Kahne D, Silhavy TJ. 2005. Chemical conditionality: a genetic strategy to probe organelle assembly. Cell. 12(2):307-17.

41. Seigler, David. 1998. Plant secondary metabolism. Springer Science Business Media New York. 1 st Edition. Page : 506-507

42. Singh A, Holvoet S, Mercenier A. 2011. Dietary polyphenols in the prevention and treatment of allergic diseases. Clin Exp Allergy, 41:1346-1359. doi: 10.1111/j.13652222.2011.03773.x

43. Skrovankova S, Sumczynski D, Mlcek J, Jurikova T, Sochor J. 2015. Bioactive Compounds and Antioxidant Activity in Different Types of Berries. Int J Mol Sci, 16: 24673-24706.

44. Villamil, O., Váquiro, H., \& Solanilla, J. F. 2017. Fish viscera protein hydrolysates: Production, potential applications and functional and bioactive properties. Food Chemistry, 224, 160-171. https://doi.org/10.1016/j.foodchem.2016.12.057

45. Yoshikawa M, Toshio M, Ning L, Akifumi N, Zian L, Hisashi M. 2005. Bioactive saponins and glycosides. XXIII.1) triterpene saponins with gastroprotective effect from the seeds of Camellia sinensis teasaponins E3, E4, E5, E6, and E7. Chemical and Pharmaceutical Bulletin. 53(12):1559-1564.

46. Zhang, B, H. Ryuji , Z. Pengxiang, K. Sato , W.Tong-Chun, L. Yang , H. Fujita , N. Mitsuda, J. Tanaka, K. Samukawa, N. Maeda, M. Sakanaka. 2006. Prevention of ischemic neuronal death by intravenous infusion of a ginseng saponin, ginsenoside $R b 1$, that upregulates Bcl-xL expression. Journal of Cerebral Blood Flow \& Metabolism (2006) 26, 708-721. 